\title{
Ghrelin is expressed in and released from mouse testicular Sertoli TM4 cells
}

\author{
Yukio Arakawa ${ }^{1}$, Sanae Yamanishi ${ }^{2}$, Syoji Matsumoto ${ }^{1}$, Ikuo Kato ${ }^{3}$, Xinmin Yu $^{3}$, Hitoshi Yanaihara ${ }^{4}$ and \\ Nobuo KurOKAWA ${ }^{1}$ \\ ${ }^{1}$ Laboratory of Pharmaceutical Sciences, Osaka University Graduate School of Medicine, D17 Suita, Osaka 565-0871, Japan; ${ }^{2}$ Clinical \\ Phrmaceuticals, Osaka University School of Pharmaceutical Sciences, Suita, Osaka 565-0871, Japan; ${ }^{3}$ Yanaihara Institute Inc., Fuji- \\ nomiya, Shizuoka 418-0011, Japan; and ${ }^{4}$ Department of Urology, Saitama Medical School, Iruma-gun, Saitama 350-0495 \\ (Received 23 August 2004; and accepted 17 September 2004)
}

\begin{abstract}
Using newly developed ghrelin specific radioimmunoassay (RIA) combined with high performance liquid chromatography (HPLC), expression and release of ghrelin/des-n-octanoyl ghrelin in mouse testicular Sertoli TM4 cells were demonstrated. The expression and release of the peptides were significantly higher than those of Leydig TM3 cells under the condition used. Testosterone $(1-100 \mathrm{ng} / \mathrm{mL})$ increased dose-dependently ghrelin release from Leydig TM3 cells but not from Sertoli TM4 cells. Both TM3 and TM4 cells possessed growth hormone secretagogue receptor (GHS-R). Implication of Sertoli cells in ghrelin expression in the testis has never been discussed. Apart from species-specificity or/and age-dependency in expression of ghrelin in different cell types of the testis, the expression and release of the peptide in TM4 cells which were found in this study raise an issue of physiological significance of ghrelin in Sertoli cells of the testis.
\end{abstract}

Ghrelin is an endogenous ligand for growth hormone secretagogue receptor (GHS-R), originally discovered in rat stomach (7). The ligand is a 28-amino acid peptide with n-octanoyl modification at $\mathrm{Ser}^{3}$. Besides the growth hormone-releasing action, ghrelin exhibits a variety of potential biological activities including orexigenic, obese, energy homeostatic, cardiovascular and prokinetic effects (3). The major site of ghrelin expression is the stomach, while the mRNA and/or peptide were found, though in much lower amounts, in a variety of central and peripheral tissues $(3,4,7)$. As to the testis, Tena-Sempere et al. (12) and Barreiro et al. (2) demonstrated, by gene expression and immunohistochemistry, that mature Leydig cells are the source of ghrelin expression in rat testis, the protein being expressed in both fetal- and adult-type Leydig cells.

We report in this communication that established

Correspondence to: Dr. Yukio Arakawa at the above address.

Tel: +81-6-6879-5980, Fax: +81-6-6879-3379

E-mail: arakawyk@msc.hosp.med.osaka-u.ac.jp two distinct testicular cell lines, derived from Leydig (TM3) and Sertoli (TM4) cells of immature BALB/C mouse testis (9), both produce and release ghrelin peptide; the expression and release of the peptide in the latter cells being significantly higher. In addition, it was demonstrated that the release of ghrelin peptide in TM3 cells, but not in TM4 cells, was significantly increased in the presence of testosterone. GHS-R gene was shown to be expressed in both of the cells.

Mouse/rat ghrelin and des-n-octanoyl ghrelin were synthesized by solid phase methodology with Fmoc-strategy using an automated peptide synthesizer, Model Pioneer (Applied Biosystems, Foster,

\section{Abbreviations:}

GAPDH, glyceraldehydes-3-phosphate dehydrogenase; GHS-R, growth hormone secretagogue receptor; HPLC, high performance liquid chromatography; PCR, polymerase chain reaction; PVDF, polyvinylidene difluoride; RIA, radioimmunoassay; SDS-PAGE, sodium dodecyl sulfate polyacrylamide gel electrophoresis; TFA, trifluoroacetic acid 
CA, USA). Anti-synthetic mouse/rat ghrelin antibodies were raised in rabbits and partially purified as described previously (1). Labeled antigen was prepared by iodination of synthetic mouse/rat ghrelin with $\left[{ }^{125} \mathrm{I}\right] \mathrm{Na}$ (Amersham Biosciences, Little Chalfont, UK) in the presence of chloramine T. Using one (RY1153) of the antibodies (final dilution $\times$ $21,000)$ and labeled antigen (about 5,000 cpm) together with mouse/rat ghrelin as standard antigen, radioimmunoassay (RIA) was carried out according to the procedure as described (1). The system was proved to be specific to C-terminal portion of ghrelin molecule and thus recognize des-octanoyl ghrelin as the authentic molecule. TM3 and TM4 cells were respectively cultured in DMEM/F12 medium (Life Technologies, Rockville, MD, USA) supplemented with $5 \%$ horse serum and $2.5 \%$ fetal bovine serum at $37^{\circ} \mathrm{C}$ in $5 \% \mathrm{CO}_{2}$. Medium was renewed at confluency of cells (at $0 \mathrm{~h}$ ), which was then sampled at $6,12,24$ and $48 \mathrm{~h}$. Cell-free medium incubated was also sampled as control at the same times. TM3 and TM4 cells collected at 24 and $48 \mathrm{~h}$ were respectively suspended in homogenate buffer (1), sonicated $(20 \mathrm{~Hz}, 15 \mathrm{sec} \times 4)$ and centrifuged $(10,000 \mathrm{~g}, 4$ ${ }^{\circ} \mathrm{C}, 15 \mathrm{~min}$ ) and the supernatant was obtained. At $80 \%$ confluent of TM3 or TM4 cells, testosterone (Wako, Osaka, Japan) was added at a final concentration of 1,10 or $100 \mathrm{ng} / \mathrm{mL}$ and the cells were incubated for $48 \mathrm{~h}$, when the medium samples were taken out. The stomach from a Wistar male rat (7 weeks old, $250 \mathrm{~g}$ ) fasted for $48 \mathrm{~h}$ was extracted with aqueous acetic acid as described elsewhere (7). The medium samples, and the supernatants of crude cell extracts and the stomach crude extract were all lyophilized and stored at $-80^{\circ} \mathrm{C}$ until used. High performance liquid chromatography (HPLC) was carried out on a reverse phase RESOURCE RPC column $(1 \mathrm{~mL})$ (Pharmacia Biotech, Uppsala, Sweden) at a flow rate of $1 \mathrm{~mL} / \mathrm{min}$ with eluent of $10 \%$ $\mathrm{CH}_{3} \mathrm{CN} / 0.1 \%$ trifluoroacetic acid (TFA) (0-5 min) and $10-50 \% \mathrm{CH}_{3} \mathrm{CN} / 0.1 \%$ TFA (5-45 min). The eluates were collected every minute. Total RNA in TM3 and TM4 cells at $24 \mathrm{~h}$ incubation was extracted with a Sepasol RNA I Super (Nacalai Tesque, Kyoto, Japan) and its template cDNA was prepared by a Superscript First-Strand Synthesis System for RT-PCR (Invitrogen, Carlsbad, CA, USA). Quantitative PCR (polymerase chain reaction) by $\mathrm{ABI}$ PRISM 7700 Sequence Detection System (Applied Biosystems) was carried out using template cDNA, Taqman Universal PCR Master Mix (Applied Biosystems) and Assay-on-Demand Gene Expression Products (FAM Probe, Mtrp-pending, Assay ID:
Mm 00445450) (Applied Biosystems) to determine ghrelin gene expression in the cells as compared with glyceraldehydes-3-phosphate dehydrogenase (GAPDH) gene expression. GHS-R protein was examined as follows; after incubation of the cells in homogenate buffer (1) containing 1\% CHAPS (Wako) for $1 \mathrm{~h}$ followed by centrifugation $(100,000 \mathrm{~g}$, $1 \mathrm{~h}, 4^{\circ} \mathrm{C}$ ), the supernatant was treated with sample buffer for sodium dodecyl sulfate polyacrylamide gel electrophoresis (SDS-PAGE) $\left(2 \mathrm{~h}, 35^{\circ} \mathrm{C}\right)$ and subjected to SDS-PAGE with $4 / 20 \%$ polyacrylamide gel (8). The proteins were transferred to polyvinylidene difluoride (PVDF) membrane (Immobilon; Millipore, Bedford, MA, USA) and immunoblotted with rabbit anti-rat GHS-R IgG (Alpha Diagnostic International, San Antonio, TX, USA) according to the method described previously (1). Data were analyzed using the unpaired two-tailed Student's t-test and presented as means with SD. A value of $p<0.05$ was considered to be significant.

A typical standard curve transformed in logit-log scale had a good linearity over the range of 3 to $772 \mathrm{fmol} /$ tube of the standard antigen. In this range, the RIA system showed appropriate precision and accuracy of intra- and interassays for ghrelin (data not shown). The dilution curves of the cell extracts and medium samples were also linear and were parallel to the standard curve and the dilution curve of the rat stomach extract, indicating that TM3 and TM4 cells produced and released ghrelin which were indistinguishable in immunological property from authentic ghrelin and rat stomach ghrelin in the current RIA system used. Time courses of ghrelin immunoreactivity (IR) in the cells and their incubation media (Fig. 1) demonstrated significantly higher rate of ghrelin-IR accumulation during 6 to $48 \mathrm{~h}$ in the culture medium of TM4 cells than in that of TM3 (2.72 folds at $24 \mathrm{~h}$ ). On the other hand, the intracellular ghrelin-IR concentrations in TM3 and TM4 cells were almost at the same levels at 24 and $48 \mathrm{~h}$. However, ghrelin gene expression at $24 \mathrm{~h}$ was significantly higher ( 2.7 folds) in TM4 cells than in TM3 cells (Fig. 2). HPLC profiles identified clearly the two major components of ghrelin-IR in the medium samples of TM3 (Fig. 3-a) and TM4 (Fig. 3-b) cells, coeluted with those in rat stomach (Fig. 3-c), as mouse/rat ghrelin and des-n-octanoyl ghrelin (shown by arrows in Fig. 3-a), respectively. The ratio of ghrelin to des-n-octanoyl ghrelin was about unity in both the cell media as in the rat stomach extract (5). The less hydrophobic (fraction 12) and more hydrophobic (fractions 30,36) components detected in TM3 (Fig. 3-a) and TM4 (Fig. 3-b) cells 


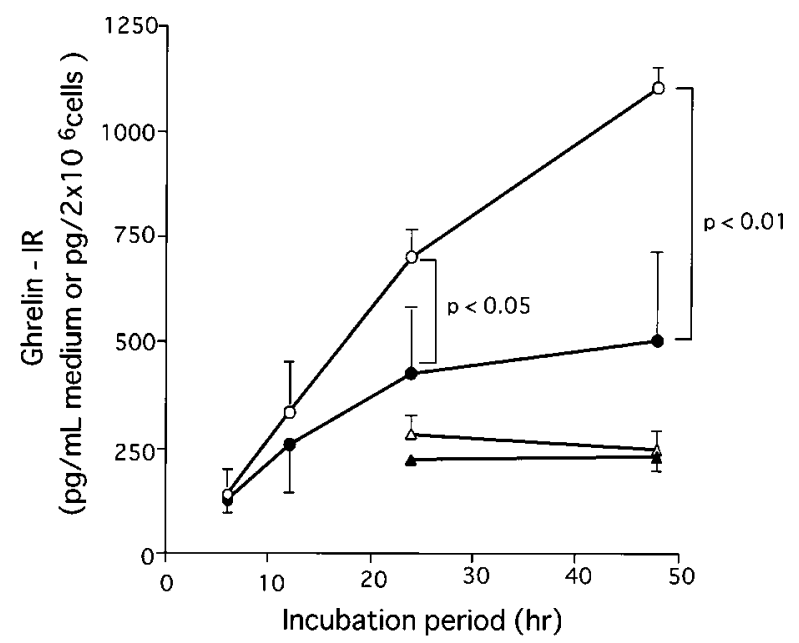

Fig. 1 Time courses of ghrelin-IR in extracts of TM3 $(\mathbf{A})$ and TM4 $(\triangle)$ cells and in culture media of TM3 $(\Omega)$ and TM4 (○) cells.

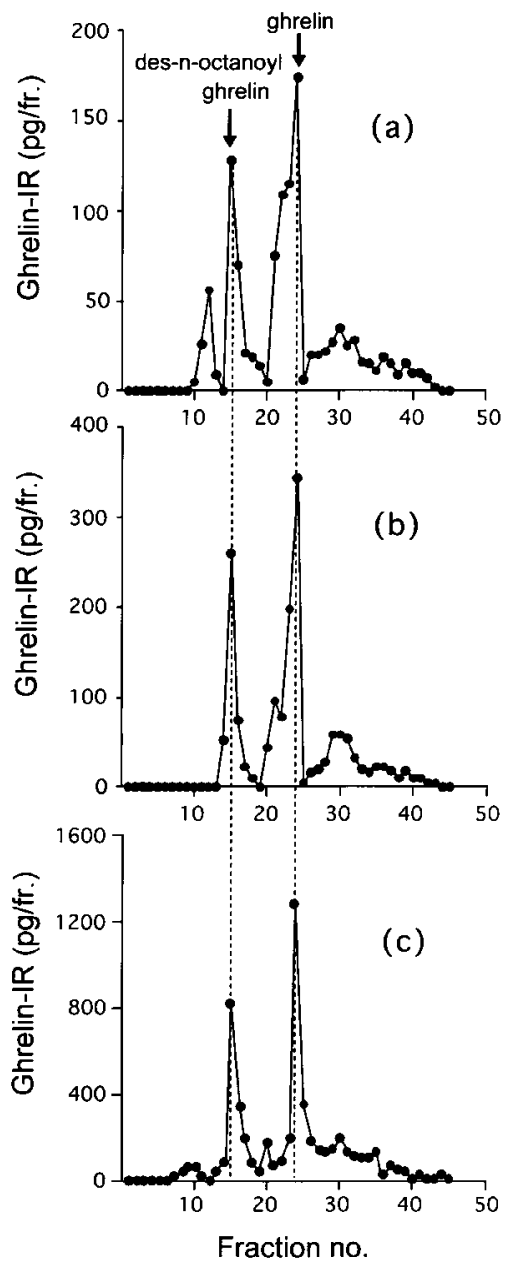

Fig. 3 Reverse phase HPLC elution profiles of ghrelin-IR in culture media of TM3 (a) and TM4 (b) cells and in rat stomach extract (c).

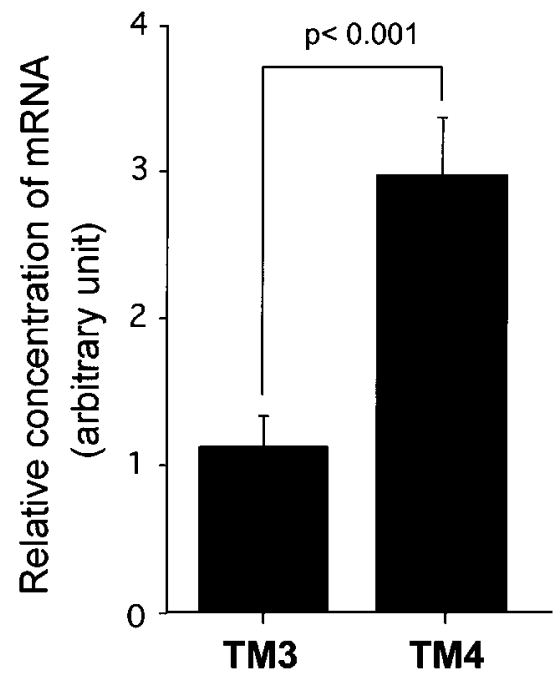

Fig. 2 Expression of ghrelin gene in TM3 and TM4 cells at $24 \mathrm{~h}$ of culture.

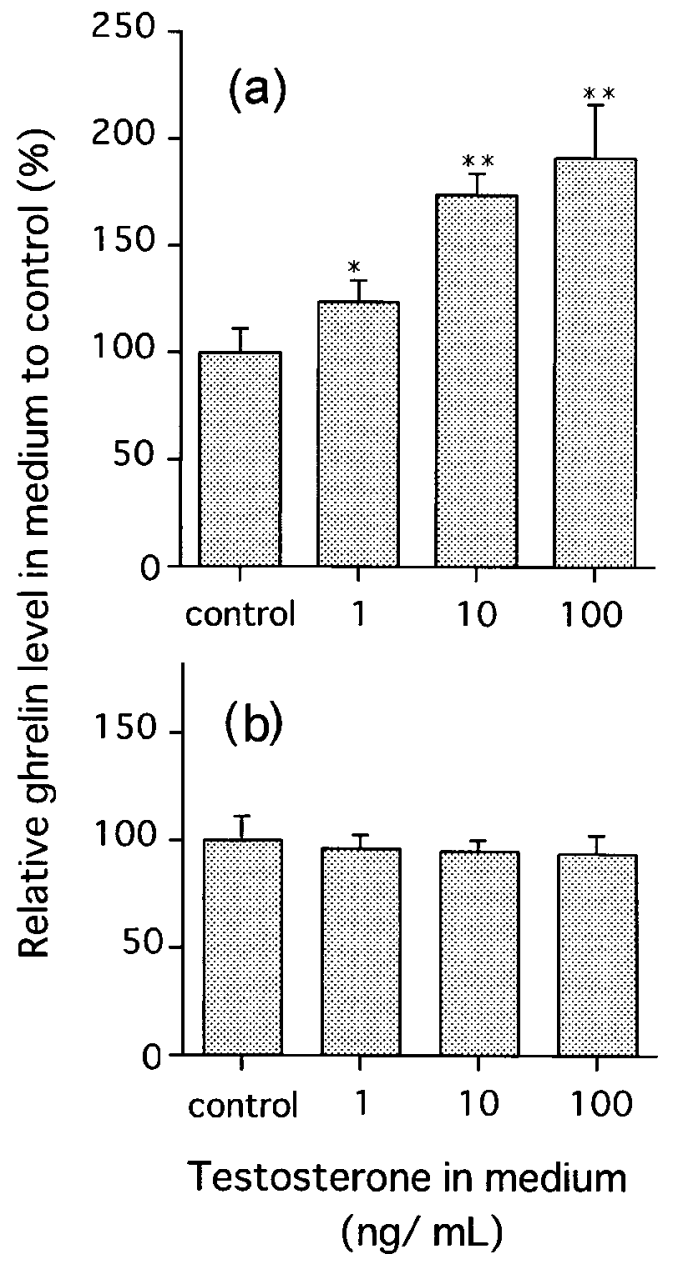

Fig. 4 Effect of testosterone on ghrelin-IR in culture media of TM3 (a) and TM4 (b) cells. ${ }^{*} \mathrm{p}<0.05,{ }^{* *} \mathrm{p}<0.01$ (vs. control). 
media remain to be identified. The existence of des$\mathrm{Gln}^{14}$-ghrelin, originally found in rat stomach (6), in the current samples, if any, was not able to be determined by the current HPLC system used. Testosterone $(1-100 \mathrm{ng} / \mathrm{mL})$ stimulated the release of ghrelinIR significantly in a dose-dependent manner in TM3 cells at $48 \mathrm{~h}$ (Fig. 4-a), but not in TM4 cells (Fig. 4-b). Immunoblot analysis revealed the presence of GHS-R1a $(44.1 \mathrm{kDa})$ in both TM3 and TM4 cell membranes (data not shown), the molecular size being similar to that of rat GHS-R1a (10).

The selective localization of ghrelin in Leydig cells of rat testis has been described $(2,12)$. A ghrelin gene-derived transcript was identified in mouse testis (11). The current result is the first demonstration that mouse testicular Sertoli cells, though a cloned cell line (TM4), express and release constitutively ghrelin and des-n-octanoyl ghrelin under the condition used. Stimulatory effect of testosterone on ghrelin peptides release from Leydig TM3 cells, which was also the first observation, and no effect on Sertoli TM4 cells substantiate differences in signal transduction cascades relating to ghrelin expression and release in the two cells. The existence of GHS-R in both Leydig TM3 and Sertoli TM4 cells suggests autocrine/paracrine regulatory signals of ghrelin peptides in both the cells.

Implication of Sertoli cells in ghrelin expression in the testis has never been discussed. Although species-specific or/and age-dependent differences in expression of the peptide in different cell types of the testis can not be excluded, the expression and release of ghrelin in TM4 cells raise an issue of physiological significance of ghrelin peptides in Sertoli cells of the testis.

\section{REFERENCES}

1. Arakawa Y, Takao E, Hirotani Y, Kato I, Li J, Yanaihara N, Yanaihara C, Iwanaga T and Kurokawa N (2002) Immunochemical characterization and measurement of neuronal type nitric oxide synthase in human neuroblastoma NB-OK-1 cell using novel anti-synthetic peptide antibody and specific immunoassay system. Regul Pept 106, 115-123.

2. Barreiro ML, Gaytan F, Camios JE, Pinilla L, Casanueva FF, Aguilar E, Dieguez C and Tena-Sempere M (2002) Cellular location and hormonal regulation of ghrelin expression in rat testis. Biol Reprod 67, 1768-1776.

3. Broglio F, Gottero C, Arvat E and Ghigo E (2003) Endocrine and non-endocrine actions of ghrelin. Horm Res 59, 109 117.

4. Gnanapavan S, Kola B, Bustin SA, Morris DG, McGee P, Fairclough P, Bhattacharya S, Carpenter R, Grossman AB and Korbonits M (2002) The tissue distribution of the mRNA of ghrelin and subtypes of its receptor, GHS-R, in humans. $J$ Clin Endocrinol Metab 87, 2988-2991.

5. Hosoda H, Kojima M, Matsuo H and Kangawa K (2000) Ghrelin and des-acyl ghrelin: two major forms of rat ghrelin peptide in gastrointestinal tissue. Biochem Biophys Res Commun 279, 909-913.

6. Hosoda H, Kojima M, Matsuo H and Kangawa K (2000) Purification and characterization of rat des-Gln ${ }^{14}$-ghrelin, a second endogenous ligand for the growth hormone secretagogue receptor. J Biol Chem 275, 21995-22000.

7. Kojima M, Hosoda H, Date Y, Nakazato M, Matsuo H and Kangawa K (1999) Ghrelin is a growth-hormone-releasing acylated peptide from stomach. Nature 402, 656-660.

8. Laemmli UK (1970) Cleavage of structural proteins during the assembly of the head of bacteriophage T4. Nature 227, 680-685.

9. Mather JP (1980) Establishment and characterization of two distinct mouse testicular epithelial cell lines. Biol Reprod 23, 243-252.

10. Shuto Y, Shibasaki T, Wada K, Parhar I, Kamegai J, Sugihara H, Oikawa S and Wakabayashi I (2001) Generation of polyclonal antiserum against the growth hormone secretagogue receptor (GHS-R). Evidence that the GHS-R exists in the hypothalamus, pituitary and stomach of rats. Life Sci $\mathbf{6 8}$, 991-996.

11. Tanaka M, Hayashida Y, Nakao N, Nakai N and Nakashima K (2001) Testis-specific and developmentally induced expression of a ghrelin gene-derived transcript that encodes a novel polypeptide in the mouse. Biochim Biophys Acta 1522, 6265 .

12. Tena-Sempere M, Barreiro ML, Gonzalez LC, Gaytan F, Zhang F-P, Caminos JE, Pinilla L, Casanueva FF, Dieguez C and Aguilar E (2002) Novel expression and functional role of ghrelin in rat testis. Endocrinology 143, 717-725. 